\title{
\%100 Yenilenebilir Enerjiye Geçiş Yolunda Dünya ve Türkiye
}

\author{
Nazlıcan Karabağ ${ }^{1}$, Cemre Belit Çobanoğlu Kayıkcı², Atakan Öngen ${ }^{3 *}$ \\ ${ }^{1}$ İstanbul Üniversitesi-Cerrahpaşa, Mühendislik Fakültesi, Çevre Mühendisliği Bölümü, İstanbul, Türkiye (ORCID: 0000-0001-6276-3597), nzlcnkrbg@ gmail.com \\ 2 İstanbul Üniversitesi-Cerrahpaşa, Mühendislik Fakültesi, Çevre Mühendisliği Bölümü, İstanbul, Türkiye (ORCID: 0000-0002-2068-4791), ccobanoglu@ ogr.iu.edu.tr \\ 3* İstanbul Üniversitesi-Cerrahpaşa, Mühendislik Fakültesi, Çevre Mühendisliği Bölümü, İstanbul, Türkiye (ORCID: 0000-0002-9043-7382), aongen@istanbul.edu.tr
} (İlk Geliş Tarihi 14 Ağustos 2020 ve Kabul Tarihi 16 Ocak 2021)

(DOI: $10.31590 /$ ejosat.780856)

ATIF/REFERENCE: Karabağ, N., Çobanoğlu Kayıkcı, C. B. \& Öngen, A. (2021). \%100 Yenilenebilir Enerjiye Geçiş Yolunda Dünya ve Türkiye. Avrupa Bilim ve Teknoloji Dergisi, (21), 230-240.

$\ddot{O} \mathbf{z}$

Çalışmada, yenilenebilir enerji kaynaklarının günümüzdeki ve gelecekteki durumu ulusal ve uluslararası yenilenebilir enerji kurumlarının geniş veri tabanları ışı̆̆ında derlenerek, \%100 yenilenebilir enerjiye geçişte dünyanın ve ülkemizin son durumu irdelenmiş, \%100 yenilenebilir enerjiye geçiş hedefine ne ölçüde yaklaşıldığı belirlenerek tüm bu bilgilerden hareketle geleceği hakkında öngörülerde bulunulmuştur. Enerji ve çevre problemlerinin gündemde olduğu günümüzde, yaşanan problemlere yönelik öncelikli çözüm ülkelerin yenilenebilir enerjiye geçişi ile mümkündür. \%100 Yenilenebilir Enerjiye Geçiş olarak adlandırılan bu hedef hem ihtiyaç duyulan enerjinin sağlanması hem de temiz enerji üretilmesi gibi avantajları beraberinde getirmektedir. Günümüzde, yenilenebilir enerji kaynakları küresel enerji kapasitesinin üçte birinden fazlasını oluşturmaktadır ve Dünya \%100 yenilenebilir enerjiye geçiş yolunda hızla ilerlemektedir. 2018 yılında 2017'ye kıyasla, toplam 181 gigawatt (GW) yenilenebilir enerji artışı olmuş ve yenilenebilir enerji paylarını büyüten ülke sayısı artmıştır. Türkiye'nin enerji üretiminde yenilenebilir enerji kaynaklarının geçmişten günümüze durumu incelendiğinde 2008 yılında \%20 olan pay 2018 'de \%32seviyelerine yükselmiştir. Fosil yakıt kaynaklı elektrik enerjisi üretimi ise 2008 'de $\% 82$ 'lık bir paya sahipken 2018 'de \%68 seviyelerine gerilemiştir. Fosil yakıt kullanımında dişarı bağımlılık ve çevresel problemler de düşünülecek olursa bu gelişme gelecek için umut verici seviyelerdedir.

Anahtar Kelimeler: \%100 Yenilenebilir Enerji, Alternatif Enerji Kaynakları, Fosil Yakıt.

\section{$100 \%$ Renewable Energy Transition Towards the World and Turkey}

\begin{abstract}
In the study, the current and future status of renewable energy sources are reviewed in the light of large databases of national and international renewable energy institutions. The latest situation of the world and our country was examined for the $100 \%$ renewable energy transition, and what extent approaches to the goal of 100\% renewable energy transition has been determined. There have been predictions about its future based on all this information. Today, energy and environmental problems are on the agenda, the solution of priority to encountered problems is possible with the $100 \%$ renewable energy transition of countries. This goal, which is called 100\% Renewable Energy Transition, brings the advantages such as providing the energy requirements, and producing clean energy. Nowadays, renewable energy sources account for over a third of global energy capacity, and the Earth is rapidly moving towards $100 \%$ renewable energy transition. Compared to 2017, there was a total increase of 181 gigawatts (GW) renewable energy, and the number of countries that increased their share of renewable energy has increased in 2018. When the situation of Turkey's energy production by renewable energy sources is analyzed from the past to the present, its share increased from $20 \%$ to $32 \%$ from 2008 to 2018. On the other hand, electricity energy production from fossil fuels had a sharp decrease from $82 \%$ to $68 \%$ in 2018 . Considering external dependence in fossil fuels, and environmental problems, this development is at a promising level for the future.
\end{abstract}

Keywords: 100\% Renewable Energy, Alternative Energy Sources, Fossil Fuel.

${ }^{*}$ Sorumlu Yazar: İstanbul Üniversitesi-Cerrahpaşa, Mühendislik Fakültesi, Çevre Mühendisliği Bölümü, İstanbul, Türkiye, ORCID: 0000-00029043-7382, aongen@ istanbul.edu.tr 
GW: Gigawatt

GWh: Gigawatt-saat

MW: Megawatt

PJ: Petajoule

TEİAŞ: Türkiye Elektrik İletim A.Ş.

TWh: Terawatt-saat

UEA: Uluslararası Enerji Ajansı

\section{Giriş}

Günümüzde enerji, dünyanın ve insanllğın en hayati ihtiyaçlarından biri haline gelmiştir. Artan talepler ve bu talepleri karşılamak için geliştirilen üretim süreçleri sebebiyle enerjiye ve enerji kullanımına olan ihtiyaç da artmaktadır. Enerji konusunda kalıcı çözümlerin bulunması için enerji problemlerinin doğru tanımlanması, uygulanabilecek çözümlerin bulunması, eski ve mevcut en iyi enerji teknolojileri arasında ayrım yapılması ve faydadan çok zarar veren eski teknolojilerin kullanılmaması gerekmektedir (Uyar ve Beşikçi, 2017; Ploetz ve diğ., 2016). Enerji piyasasına ve enerji ihtiyacına bakıldığında fosil yakıtlar baskı altındadır ve bu durum henüz olgunlaşmaya yeni başlamış olan yenilenebilir enerji piyasasını avantajlı kılmaktadır. Yenilenebilir enerji; sürekli olarak devam eden doğal süreçlerdeki var olan enerji akışından elde edilen enerjidir ve güneş enerjisi, rüzgâr enerjisi, jeotermal enerji, hidro enerji, okyanus enerjisi, biyokütle enerjisi ve hidrojen enerjisi yenilenebilir enerji kaynakları olarak sıralanabilir (URL1).

Küresel iklim değişikliği ve çevre problemlerine sebep olmasıyla fosil yakıtlar kritik bir problem oluşturmaktadır. Fosil yakıtlar, sonsuz kaynaklar değildir ve tükenme tehlikesiyle karşı karşıyadır. Fosil yakıtların enerji üretiminde kullanılmasıyla oluşan sera gazları sebebiyle hem iklim değişimi hem de ekolojik denge bozulmaları gözlenmektedir. Fosil yakıt kaynaklarının sınırlandırılıyor olması, enerjinin kullanılabilirliğinin garanti edilmesi için enerji kaynaklarının çeşitlendirilmesini gerektirmektedir. Yeni ve yenilenebilir enerji kaynaklarına yönelinmesinın geleceğin enerji ihtiyaçlarının karşılanmasında doğru bir adım olacağı ön görülmektedir (Ploetz ve diğ., 2016).

Teknolojik gelişmeler, sanayileşme ve yaşam standartlarının yükselmesiyle birlikte Dünya'daki siyasi sürecin şekillenmesinde ülkelerin enerji kaynakları, bu enerji kaynaklarını nasıl kullandıkları, kullanım verimleri ve değerlendirme, denetleme ve geliştirebilme şekilleri de etkili olmaktadır. Ülkelerin enerji bağımsızlıkları siyasi olarak belirleyicilik katmaktadır. Tüm bu sebepler nedeniyle geleceğe yönelik oluşturulan üretim planlamalarında yenilenebilir enerji kaynaklarının kullanımının arttırılmasına yönelik çalışmalar da hız kazanmaktadır (Sadiqa ve diğ., 2018; Kılıçkaplan ve diğ, 2017; Hansen ve diğ., 2019).

Ülkemizde de artan enerji talebini karşılamak, enerji kaynaklarında dışa bağımlılığı azaltmak ve çevre dostu bir üretim yapabilmek için yenilenebilir enerji kaynaklarından en üst seviyede faydalanmak büyük önem taşımaktadır. Ülkemizde çeşitli yenilenebilir enerji kaynaklarının ekonomiye katma değer sağlayabilecek ölçüde değerlendirilebilir potansiyeli bulunmaktadır. Sahip olunan potansiyelin tam anlamiyla kullanılamıyor olması gerek ülke ekonomisini bask1 altına almakta gerekse başta hava kirliliği ve iklim değişikliği olmak üzere ekosistem üzerinde olumsuz etkilere neden olmaktadır.
Global ölçekte de yaşanan benzer problemlerin iyileştirilmesine yönelik en güncel ve etkili çözüm önerisi ise "\%100 Yenilebilir Enerjiye Geçiş" yaklaşımı olarak kabul edilmektedir. Yenilenebilir enerji, istenen kalitede enerji üretiminin gerçekleştirilmesine ve dönüştürülmesine uygun olan yüksek entropi kaynaklarını içermektedir (Uyar ve Beşikçi, 2017). \%100 Yenilenebilir enerjiye geçişin faydaları şöyle siralanabilir:

- Yakıt zenginliği,

- Enerji fiyatlarında olası düşüş,

- Enerjide dışa bağımlılığın azaltılması,

- Güvenli ve temiz bir enerji üretimi,

- Hava, su ve çevre kirliliğinin iyileştirilmesi, halk sağlığının korunmasi

- Yerel ekonominin düzenlenmesi (URL2; Ploetz ve diğ., 2016).

Elbette yenilenebilir enerji kaynaklarının temiz enerji olması ve sonsuz olması gibi avantajlarının yanında dikkate alınması gereken dezavantajları da vardır. Bunlar sinırlı potansiyel, yüksek maliyet ve enerji yoğunlukları ile ilgilidir. Yenilenebilir enerji kaynaklarının enerji üretiminde kullanılması için yapılacak projelerin ilk yatırım maliyetlerinin çok yüksek olması ve enerji depolama sorunlarının varlığ yenilenebilir enerji kaynaklarının kullanımında dezavantaj yaratmaktadır (Ploetz ve diğ., 2016).

Yenilenebilir enerji kaynakları şu anda küresel enerji kapasitesinin üçte birinden fazlasını oluşturmaktadır. 2018'de doksandan fazla ülkede $1 \mathrm{GW}$ 'dan fazla yenilenebilir güç kapasitesi kurulmuştur. Son yıllarda enerjinin \%100'ünü yenilenebilir kaynaklardan karşılama yönünde artan bir hareket şehirlerde ve ülkelerde görülmektedir. Norveç, Kosta Rika, Çin, Almanya ve İsveç gibi ülkeler yerel enerji sektörlerinin hedeflerini "\%100 yenilenebilir enerji kaynaklarına geçiş" olarak belirlemişlerdir (URL3; Child ve diğ.,2019).

Yenilenebilir Enerjiler 2019 Küresel Durum Raporu'na göre 2018 y1lı, yenilenebilir enerji teknolojileri için nispeten istikrarlı bir piyasa yaşamıştır, 2017'ye kıyasla, toplam 181 gigawatt (GW) yenilenebilir enerji artı̧ı olmuş ve yenilenebilir enerji paylarını büyüten ülke sayısı artmaya devam etmektedir. Yenilenebilir enerji kaynakları, yıl sonuna kadar küresel elektrik üretiminin tahminen \%26'sından fazlasını sağlamıştır ancak yenilenebilir enerji seçenekleri, ısıtma ve ulaşım için gerekli olan enerjinin sadece \%10'unu ve \%3'ünü sağlamaktadır. Enerji, ısıtma, soğutma ve ulaştırma sektörleri arasındaki entegrasyonu geliştirmek için, yenilenebilir teknolojilerin ve firsatların arttırılması, tamamen yenilenebilir enerjiye dayalı bir dünyaya geçişi sağlayacaktır (Murdock ve diğ., 2019).

Türkiye'nin enerji üretiminde yenilenebilir enerji kaynaklarını kullanması ise geçmişten günümüze artmaktadır. 
Son 10 yıllık gelişime bakıldığında 2008 yılında yenilenebilir üretimin pay1 \%19,58 iken 2018 'de bu pay \%32,08 olmuştur. Fosil yakıt kaynaklı enerji üretimine bakıldığında ise 2008 'de $\% 82,06$ 'lık bir paya sahipken 2018'de bu pay \%67,60'a düşmüştür. $\mathrm{Bu}$ bilgiler de Türkiye'de $\% 100$ yenilenebilir enerjiye geçişte önemli aşamalar kaydedildiğini göstermektedir (URL4).

2013 yılında ivme kazanmaya başlayan \%100 yenilenebilir enerjiye geçiş yatırımları, 2015 yılının sonuna doğru istikrarlı bir şekilde artmış ve 290 milyar dolara ulaşmıştır. Atmosfere salınan karbon dioksit emisyonlarının azalması ve daha sağlıklı bir ortam oluşması sebebiyle $\% 100$ yenilenebilir enerjiye geçiş, tüm insanlığa sürdürülebilir bir yapı içinde sağlıklı bir yaşam sunmanın tek yolu olarak görülmektedir. Mevcut yenilenebilir enerji teknolojilerinin kullanılmasıyla 2050 yılına kadar \%100 yenilenebilir enerjiye geçmiş bir Dünya olabilmek için, tüm yenilenebilir enerji kaynaklarının bir arada kullanılması ve depolama teknolojilerinin geliştirilmesi gerekmektedir (Uyar ve Beşikci, 2017).

Ülkelerin enerji ihtiyacını karşılarken kullandıkları doğal kaynakların çıkarılması ve kullanılması için uygulanan teknolojilere bağlı olarak gerek ulusal ekonomilerin gerekse çevresel kaynakların üzerindeki olumsuz etkilerinden dolayı yaşanan global baskılar \%100 yenilenebilir enerjiye geçiş politikalarının uygulanmasını kaçınılmaz kılmaktadır. $\mathrm{Bu}$ bağlamda, çalışmada uluslararası kabul görmüş, güncel istatistiki bilgilerin kaydının tutulduğu uluslararası kurumların kaynakları ve akademik makaleler derlenerek okuyucuların konuyla ilgili en güncel bilgilere bir bütün halinde erişmeleri hedeflenmiştir. $\mathrm{Bu}$ bağlamda elde edilen veriler 1şığında, ülkemiz için \%100 yenilenebilir enerjiye geçiş hedefi doğrultusunda ülkenin sosyoekonomik yapısına uygun bir yol haritasının ortaya konması amaçlanmıştır.

\section{Yenilenebilir Enerji Kaynakları}

Bu bölümde yenilenebilir enerji kaynaklarının uluslararası ölçekte güncel durumu hakkında kısaca bilgiler verilmiştir.

\subsection{Biyokütle}

Biyokütle, fosil yakıt kaynaklarının yerini alacağı düşünülen önemli bir yenilenebilir ve sürdürülebilir enerji kaynağıdır. Odun, tarımsal ürünler, tarımsal yan ürünlerin atıkları, hayvan atıkları, belediye katı atıkları, atıksu arıtma tesislerinden çıkan arıtma çamurları, gıda işlemeden kaynaklanan atıklar, su bitkileri ve algler biyokütlenin en önemli kaynaklarıdır. Son istatistiklere göre, Türkiye'de 2018 yılında üretilen belediye atık miktarı yaklaşık 32.2 tondur (Kanat ve Ergüven, 2020). Biyokütle ve biyoenerjinin 1s1 ve güç üretimi, kimyasal ve yakıt üretiminde küresel enerji senaryosunun geleceğinde hayati bir rol oynayacağı ön görülmektedir. Son yıllarda biyoenerji, fosil yakıt kaynaklarının azalması ve çevresel kaygıların artmasıyla birlikte özel ilgi görmektedir. Biyoenerji, gelişmekte olan ülkelerde yoksulluğun azaltılmasına katkıda bulunmaktadır. Biyoenerji, karmaşık enerji dönüştürme ve pahalı süreçler olmadan her zaman gerekli enerjiyi sağlaması ve çevre dostu olması gibi avantajlarıyla, enerji gereksinimlerini karşılayan ve gelecekte de enerji taleplerini karşılayabilecek en iyi alternatif yakıt olarak düşünülmektedir. 2050 yılına kadar, dünyanın birincil enerjisinin $\% 25$ 'inden fazlasının biyokütleden elde edileceği öngörülmektedir (Hosseini ve Wahid, 2016; Avcioğlu ve Dayığlu, 2019).
Biyoenerji, küresel yenilenebilir enerji arzına en önemli katkıyı yapan enerji kaynakları arasındadır. 2017 sonu itibariyle nihai global enerji tüketimine tahmini \%12,4 katkıda bulunduğu raporlanmıştır. Küresel ısıtma arzının \%5'i, ulaşımın \%3'ü, elektrik arzının ise \%2'si biyoenerjiden sağlanmıştır. 2018 yılı verilerine göre Çin bu alanda dünya lideri olurken ABD, Brezilya, Hindistan ve Almanya ise Çin'i takip eden ülkeler arasında yer almışlardır (Renewables 2019, Global Status Report).

\subsection{Jeotermal Enerji}

Yerkürenin iç 1sısı olan jeotermal enerji, bu iç ısının merkezdeki sıcak bölgeden yeryüzüne doğru yayılması prensibine dayanır ve elektrik enerjisi üretiminde, 1sıtmada, tarım, seracılık, balıkçılık gibi birçok alanda kullanılır. Dünya jeotermal enerji kurulu gücü; elektrik ve 1sı üretim gücü olmak üzere iki şekilde ifade edilmektedir. 2018'deki toplam jeotermal enerji üretiminin 630 PJ olduğu tahmin edilmektedir, bunun yaklaşık yarısı elektrik amaçlı (89,3 TWh) kullanılmaktadır. 2018 y1lında 0.5 GW'lık yeni bir jeotermal enerji kapasitesi oluşmuş ve küresel toplam 13,3 GW olmuştur (Kaygusuz, 2019).

Türkiye ve Endonezya 2018 yılı itibarıyla jeotermal enerji kapasitesini faydalı kullanıma çevirme oranı açısından sıralamanın ilk iki basamağını oluşturan ülkelerdir. Bu iki ülkeyi ABD, İzlanda, Yeni Zelanda, Hırvatistan, Filipinler ve Kenya takip etmektedir. Türkiye 2018 yılında tamamladığı jeotermal enerji projeleriyle kurulu kapasitesini \%21(219 MW) arttırıp 1.3 GW'a yükseltmiştir. Endonezya jeotermal kapasitesini $140 \mathrm{MW}$ arttırmış ve kurulu kapasitesini 1,95 GW'a yükseltmiştir (Kaygusuz,2019; Renewables 2019, Global Status Report). Kaynak rezervi açısından ise ABD, Endonezya, Filipinler, Türkiye, Yeni Zelanda, Meksika, İtalya, İzlanda, Kenya ve Japonya şeklinde sıralanmaktadırlar.

Maden Tetkik ve Arama Genel Müdürlüğü 2019 verilerine göre Türkiye'nin jeotermal enerji haritası incelendiğinde, Türkiye'nin özellikle Ege bölgesinde yoğun bir jeotermal enerji potansiyeli olduğu görülmektedir. Ülkemiz jeolojik ve coğrafik konumu itibariyle aktif bir tektonik kuşak üzerindedir ve jeotermal açıdan zengin bir durumdadır. Ülkemizin her tarafinda dağılmış değişik sıcaklıklarda yaklaşık 1.000 adet doğal çıkış şeklinde jeotermal kaynak bulunmaktadır. Ülkemizde yüksek jeotermal enerji potansiyeli oluşturan alanların \%78'i Batı Anadolu'da, \%9'u İç Anadolu'da, \%7'si Marmara Bölgesi'nde, \%5'i Doğu Anadolu'da ve \%1'i diğer bölgelerde yer almaktadır. Türkiye'deki jeotermal kaynakların \%90'1 düşük ve orta sicaklıkta olup doğrudan uygulamalar (1sitma, termal turizm, çeşitli endüstriyel uygulamalar vb.) için, \%10' $\mathrm{u}$ ise dolaylı uygulamalar (elektrik enerjisi üretimi) için uygun durumdadır (URL5).

\subsection{Hidroenerji}

Hidroelektrik, elektrik talebindeki artış, türbin verimliliğindeki artış gibi faktörlerin etkisiyle elektrik üretiminde rolünü büyük ölçüde genişletmiş, bilhassa Asya, Latin Amerika ve Afrika'daki gelişmekte olan pazarlarda rağbet görmüş yenilenebilir bir enerji kaynağıdır. 2018 yılında küresel hidroelektrik pazarında toplam kurulu güç $20 \mathrm{GW}$ artmış ve 1132 GW'a ulaşmıştır. Toplam hidroelektrik kapasitesinde ilk 10 ülke (sırasıyla) Çin, Brezilya, Kanada, Amerika Birleşik Devletleri, Rusya Federasyonu, Hindistan, Norveç, Türkiye, Japonya ve Fransa yer almaktadır ve bu ülkeler küresel 
kapasitenin üçte ikisini temsil etmektedir (Pandey ve Karki, 2016; Renewables 2019, Global Status Report).

\subsection{Okyanus Enerjisi}

Geniş ve güçlü okyanuslar dünya genelinde toplam enerji talebini birçok kez karşılayacak 1sı, akım, dalga ve gelgit şeklinde yeterli enerji depolamaktadırlar. Ancak, buna rağmen günümüzde okyanus enerjisi dünya çapında enerji arzının sadece küçük bir bölümünü oluşturmaktadır. Şimdi ise küresel iklim değişikliği ve dünya çapında fosil yakıtlara bağımlılığın diğer çevresel etkilerinin yarattığı endişeler, yenilenebilir enerjiye ve okyanus enerjisine olan ilgiyi arttırmıştır. Gelecekte yenilenebilir enerjilere olan küresel bağlılık arttıkça, okyanustaki büyük enerji depolarına daha fazla ilgi artacaktır. Okyanus enerjisi, yenilenebilir enerji pazarının en küçük bölümünü temsil eden yenilenebilir enerji kaynağıdır. $\mathrm{Bu}$ enerji türüyle yapılan projelerin çoğu da küçük ölçekli ve pilot projeler olmaktadır ve 2018'de 532 MW işletme kapasitesi olduğu hesaplanmıştır. Okyanus enerjisinin kaynak potansiyeli yüksek olmasına rağmen, maalesef kullanımı yaygın değildir. Özellikle Avrupa ve Kuzey Amerika'daki hükümetlerin okyanus gücü teknolojilerini desteklemesi, okyanus enerjisi ile elektrik üretimini güçlendirmeye başlamıştır (Renewables 2019, Global Status Report; Wilberforce ve diğ., 2019).

\subsection{Güneş Enerjisi}

Güneş enerjisi, birincil enerji kaynağı olarak kabul edilen ve 1sıtma, mimari, kentsel planlama, tarım, bahçecilik, ulaştırma ve yakıt üretimi uygulamalarında yaygın olarak uygulanan bir enerji kaynağıdır. Gelişmekte olan pazarlarda ve Avrupa'da güneş enerjisine olan talep giderek artmaktadır. Güneş enerjisi 2018 yılında en yüksek elektrik üretimi değerlerini görmüş, küresel anlamda en çok rağbet gören yenilenebilir enerji türlerinden biri olmuştur. Güneş enerjisinde yıllık küresel pazara 100 GW'1 aşkın kapasite eklenmiş ve yıl sonunda toplam kapasite 505,5 GW olmuştur. Özellikle Amerika Birleşik Devletleri ve Avrupa'da önemli ölçüde güneş enerjisi kapasitesi artmıştır. Ayrıca dünyanın dört bir yanında madencilik, imalat ve diğer endüstriler faaliyetlerini yürütmek için güneş enerjisi tesisleri kurmaktadır. 2018 y1lı sonuna kadar en az 32 ülkede güneş enerjisi kapasitesi $1 \mathrm{GW}$ ve üstünde artmıştır. Güneş enerjisinde Çin, küresel kapasitenin yaklaşık \%74'ünü oluştururken, bunu Türkiye, Brezilya ve ABD izlemektedir

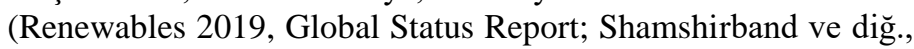
2019).

\subsection{Rüzgar Enerjisi}

Rüzgar enerjisi, küresel pazarı oldukça istikrarlı bir şekilde gelişen ve 2018'de yaklaşık kapasitesini 51 GW arttıran yenilenebilir bir enerji kaynağıdır. Rüzgar enerjisi kapasitesi 2018 y1lında \%9 artarak 591 GW'a yükselmiştir. 2017'de Avrupa ve Hindistan'da rüzgar enerjisi kapasitesinde rekor yaşanmıştır ancak bu durum 2018 yılında aynı istikrarı gösterememiştir, buna karşılık diğer bölgelerde ve ülkelerde dikkate değer bir büyüme yaşanmıştır. En büyük bölgesel pazar ise \%52 ile Asya olmuştur. Avrupa'daki yedi, Asya'daki iki ülke kapasitesini 4,5 GW arttırmış ve küresel kapasiteyi \%24 artırarak 23,1 GW'a ulaşmıştır (Renewables 2019, Global Status Report; Shamshirband ve diğ., 2019).

\subsection{Hidrojen Enerjisi}

Bugünün artan yatırımları ve daha ucuz yenilenebilir enerji arzı, hidrojen üretim maliyetlerini etkileyecek ve fosil yakıtlardan ucuz yenilenebilir enerjiye yönelimi artıracaktır. Bu gerçek, hidrojen enerjisi teknolojilerinin \%100 yenilenebilir enerji hedefine ulaşmada önemli bir rol oynayacağını doğrulamaktadır (Uyar ve Beşikçi, 2017; Abe ve diğ., 2019).

Hidrojen, yaklaşık sıfır emisyon üretmesi ve doğada bol bulunan kaynakları ideal bir sürdürülebilir enerji kaynağı olabilir. Hidrojenin tersine, fosil yakıt kaynakları, hava kirliliği ve küresel ısınma gibi ciddi çevre sorunlarına yol açmaktadır. Fosil yakıt kullanımının çevre, insan sağlığı ve iklim üzerindeki olumsuz etkilerini gidermek için temiz ve zengin kaynaklardan çevreye zararsız metotlarla hidrojen üretilmelidir. Yenilenebilir enerji kaynaklarından üretilen hidrojen enerjisi, kalıcı bir enerji sisteminin önünü açacaktır (Karabağ, 2018; Veziroğlu ve Şahin, 2019).

Hidrojen enerjisinin yaygınlaşabilmesi için dünyada birçok proje üretilmekte ve çeşitli pilot tesisler kurulmaktadır. Türkiye'de hidrojenle çalışan otobüs ve Bozcaada'da yer alan rüzgardan hidrojen üretimi projeleri pilot tesis çalışmaları arasındadır. Bunun dışında Dünya'da da birçok pilot ölçekli proje örnekleri bulunmaktadır. Örneğin; Çin'de hidrojen üretimi için kurulan küçük hidroelektrik santraller, Arjantin'de bulunan hidrojen üreten rüzgar türbinleri, Güney Kore ve Hindistan'daki hidrojen yakıtlı taşıtlar bu çalışmalar örnektir. Bununla birlikte, Libya'da güneş panelleriyle hidrojen üretiminin sağlanması planlanmakta, Portekiz, Kolombiya, Misır, Rusya ve İtalya gibi ülkelerde de hidrojen kullanımı yaygın hale gelmektedir (Mutlubaş ve Özdemir, 2019).

\section{3. \%100Yenilenebilir Enerji}

Fosil yakıtlar kaynakları arzın artması, çevre kirliliği ve iklim değişikliği sorunları ile karşı karşıyadır, yenilenebilir enerji ise enerji konusunda en iyi beklentileri sunabilmektedir. Yenilenebilir enerji kaynakları fosil yakıtlardan birçok önemli açıdan farklı olmaktadır.

$\% 100$ yenilenebilir enerjiye geçiş kavramı, enerjinin kullanıldığı tüm alanlarda bilhassa elektrik üretimi, ulaşım ve 1sıtma/soğutmada tamamen yenilenebilir enerji kaynaklarının kullanılması anlamını taşımaktadır. $\mathrm{Bu}$ hedefin başarılması sürdürülemez olan enerji talebinin azaltılmasına, enerji verimliliğinin arttırılmasına, çok daha ucuz ve çok daha temiz enerji üretilmesine olanak sağlayacaktır.

Bu bölümde hem Dünya'da hem de Türkiye'de \%100 yenilenebilir geçmişte geçmişten bugüne kat edilen yol hakkında bilgi verilmiş, küresel ve yerel anlamda \%100 yenilenebilir enerjiye geçişi hızlandırmak için yapılanlar konusunda açıklamalar yapılmıştır.

\subsection{Dünyada \%100 Yenilenebilir Enerjiye Geçiş}

Isıtma, soğutma ve ulaşımda çok daha az büyüme yaşanırken, yenilenebilir enerji sektöründeki ilerleme, elektrik üretimi alanında yoğunlaşmaya devam etmektedir. Elektrik, küresel enerji tüketiminin sadece beşte birini oluşturmaktadır, ulaşım ve ısıtma sektörlerindeki yenilenebilir enerjilerin rolü enerji geçişi için kritik önemini halen korumaktadır. Küresel olarak bakıldığında 2018 yılı \%100 yenilenebilir enerjiye geçişte istikrarlı bir profil çizmiştir. 2017'ye göre $181 \mathrm{GW}$ yenilenebilir 
enerji eklenmiş ve \%100 yenilenebilir enerjiye geçişte yol kat eden ülke sayısı artmıştır. Yenilenebilir enerji sektörü genel olarak 2018'de dünya genelinde 11 milyon civarında (doğrudan ve dolaylı) istihdam sağlamıştır. $\% 100$ yenilenebilir enerjiye geçişte enerji verimliliğinde ve geçişte ilerleme kat edilmesine rağmen küresel anlamda Dünya Sürdürülebilir Kalkınma hedeflerinin ve Paris Anlaşması'nın gerisindedir. Küresel enerji kaynaklı karbondioksit $\left(\mathrm{CO}_{2}\right)$ emisyonları, fosil yakıt tüketimindeki artış nedeniyle 2018 'de \%1,7 oranında artmıştır. Fosil yakıt kullanımı 2017'den bu yana \%11 artmıştır. Fosil yakıt şirketleri, iklim değişikliği politikalarını geciktirmek, kontrol etmek veya engelleyip, kamuoyunu etkilemek için reklamlara yüzlerce milyon dolar harcamaya devam etmektedir.

Şekil 1'de \%100 yenilenebilir enerjiye geçişte diğer ülkelere göre bir adım önde olan ülkelerle Türkiye'nin yenilenebilir enerji üretimleri karşılaştırılmıştır.

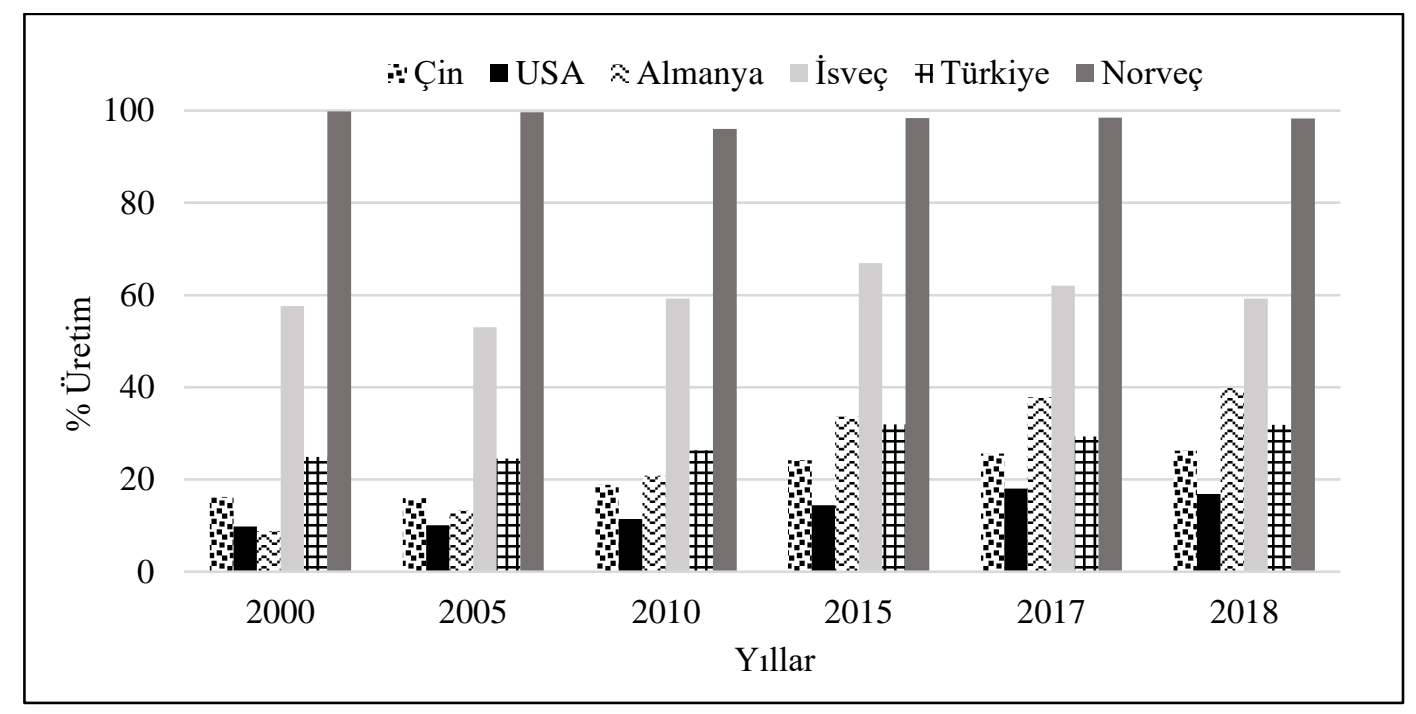

Şekil 1: Ülkelerin Yenilenebilir Elektrik Enerjisi Üretimi (\%) (UEA,2019; URL6).

$\% 100$ yenilenebilir enerjiye geçişte diğer ülkelere göre bir adım önde olan Çin, Amerika Birleşik Devletleri, Almanya, İsveç ve Norveç'in yenilenebilir enerji üretimlerinin Türkiye ile karşılaştırıldığı Şekil 1 incelendiğinde, Norveç'in \%100 yenilenebilir enerjiye geçiş yaptığı, elektrik enerjisinin tamamını yenilenebilir enerjiden karşıladığı görülmektedir. \%100 yenilenebilir enerjiye geçişe en yakın olan İsveç ise ikinci sırada Norveç'i takip etmektedir. Çin, ABD ve Almanya da giderek artan yenilenebilir enerji profilleriyle $\% 100$ yenilenebilir enerjiye geçişte yol kat eden ülkelerdir. Türkiye'ye bakıldığında ise 2000 yılından bu yana \%100 yenilenebilir enerjiye geçişte yenilebilir elektrik enerjisi üretiminde Çin, ABD ve Almanya'nın ilerisindedir.

Şekil 2'de ülkelerin yenilenebilir üretiminin toplam tüketim içerisindeki payı verilmiş, toplam tüketim içerisindeki yenilebilir üretimin ne durumda olduğu hakkında bilgi verilmiştir.

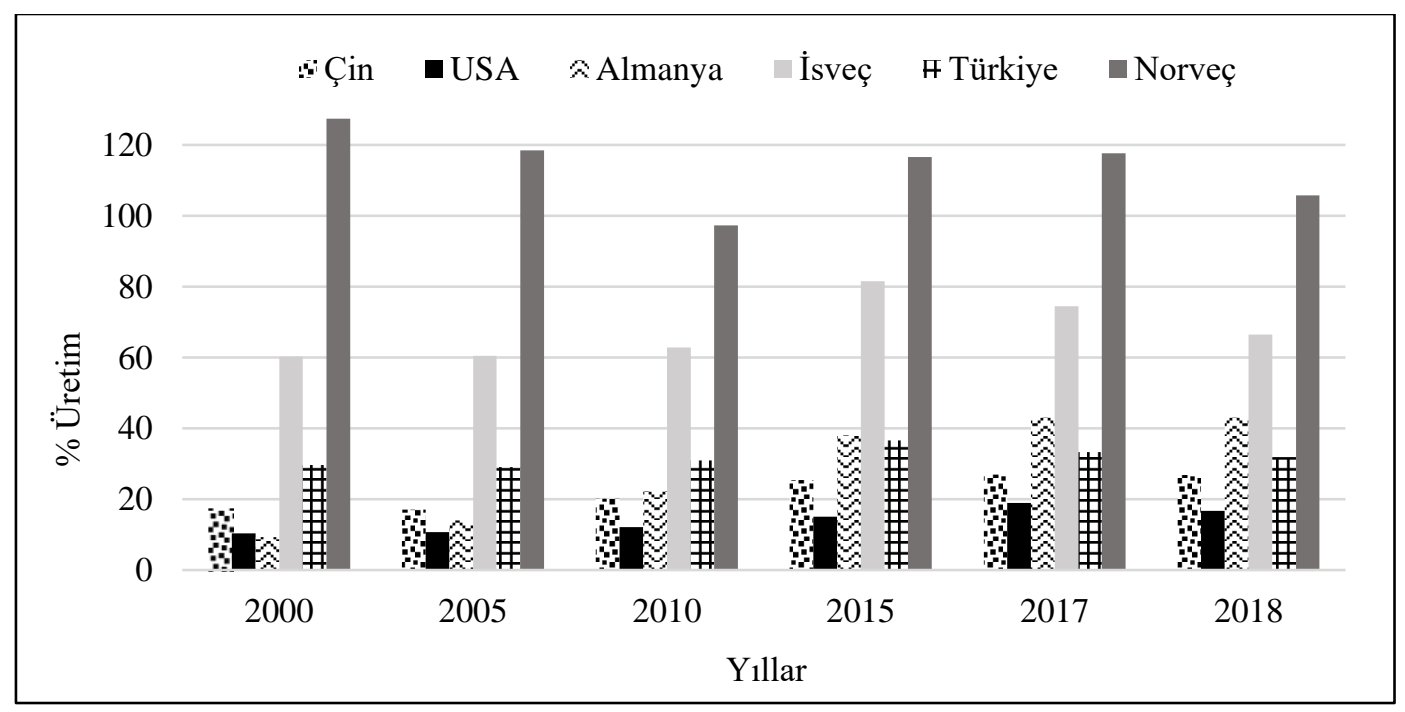

Şekil 2: Ülkelerin Yenilenebilir Üretiminin Toplam Tüketim İçerisindeki Payı (UEA,2019; URL7).

Şekil 2'deki veriler istatiksel olarak analiz edildiğinde, toplam tüketim içerisindeki yenilenebilir üretimin payının en yüksek olduğu ülke Norveç’tir, hatta grafik incelendiğinde
Norveç'te tüketimden daha fazla yenilenebilir üretimin olması sebebiyle \%120'ye yaklaşan hatta \%120'yi bile aşan üretim payları görülmektedir. Norveç'i ikinci sırada İsveç takip 
etmektedir. Türkiye'nin toplam tüketim içerisindeki yenilenebilir payı ise Almanya'dan düşüktür. Çin ve ABD'de ise yenilenebilir üretim payının düşük olduğu görülmektedir. Şekil 3 'te ise ülkelerin yıllara göre elektrik enerjisi tüketimleri verilmiştir.

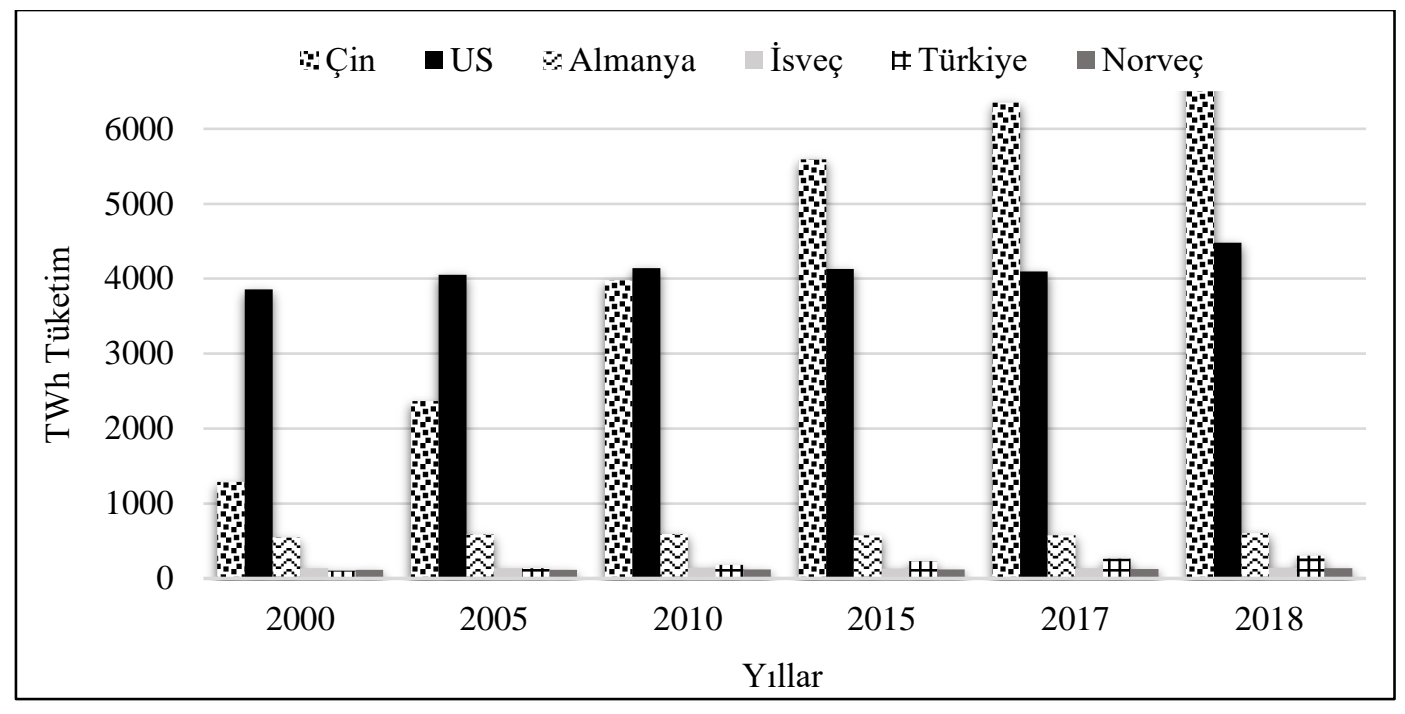

Şekil 3: Ülkelerin Elektrik Enerjisi Tüketimleri (TWh) (UEA, 2019; URL7).

Şekil 3 incelendiğinde, yenilenebilir üretim payının düşük olduğu Çin'de toplam elektrik enerjisi tüketimi 2018 yllında 6500 TWh'dır, bunun sadece yaklaşık çeyreği yenilenebilir enerji üretiminden karşılanabilmektedir. Bu durum ABD için de geçerlidir, 2018 yılında 4500 TWh elektrik enerjisi tüketimine rağmen bu enerjinin sadece yaklaşık \%18'i yenilenebilir üretimden karşılanmaktadır. $\mathrm{Bu}$ bilgiler 1şı̆ı̆nda enerji tüketiminin fazla olmasına rağmen İsveç dışında birçok ülkenin bu tüketim payı içerisindeki yenilenebilir üretim payının düşük olduğu ve tüketilen enerjinin yenilenebilir üretimle karşılanamayacağı, karşılanması için daha kat edilmesi gereken çok yol olduğu görülmektedir.

$\% 100$ yenilenebilir enerjiye geçişi hedefleyen ülkelerin bu hedefi gerçekleştirmek için küçük veya büyük birçok atılımı vardır. 2018 yılı Uluslararası Enerji Ajansı verilerine göre yenilenebilir enerji kaynaklı küresel elektrik üretimi payı \%26 olarak hesaplanmıştır. $\mathrm{Bu}$ durum küresel çapta \%100 yenilenebilir enerjiye geçişe $\% 26$ oranında geçiş yapıldığı göstermektedir. 2018 yılına kadar, 169 ülkede ulusal veya eyalet/il düzeyinde $\% 100$ yenilenebilir enerjiye geçiş hedeflenmiştir. Otobüslerin hava kirliliğine diğer toplu taşıma araçlarına göre daha fazla olumsuz katkıda bulunmasından dolayı yenilenebilir bir güce geçmek için Uganda'da güneş otobüsleri, Hindistan'da güneş feribotu, Hollanda'da rüzgar enerjili trenler kullanılmaya başlanmıştır. Ayrıca ülkelerin \%100 yenilenebilir enerji yolunda ilerlemek için yürüttükleri bir dizi politika önlemi de bulunmaktadır. Avustralya'da New South Wales Üniversitesi dünyanın tamamen güneş enerjisiyle çalışan ilk üniversitesi olmuştur, 2020 yllına kadar $\% 100$ güneş enerjisiyle çalışmaya başlayacaktır. Yine Kenya'daki birçok üniversite (Strathmore ve Kenyatta Üniversiteleri dahil), enerji tedariği için güneş panelleri kullanmaktadır ve ürettikleri elektriği aynı zamanda ulusal şebekeye satarak para kazanmaktadır. İskoçya, 2020 yılına kadar tüm elektrik enerjisini yenilenebilir enerji kaynaklarından üretmeyi hedeflemektedir. Arnavutluk, Norveç ve Kosta Rika \%100 yenilenebilir enerjiye geçiş sağlamış ülkelerdendir. Hollanda demiryolu ağı sistemlerinde, trenlerinin $\% 100$ ' üne rüzgar enerjisi ile güç vermektedir. İngiltere'deki 21 Katolik Piskoposluk'tan 16's $\% 100$ yenilenebilir enerjiye geçiş yapıp, yenilenebilir enerji satın alma sözü vermiş̧tir. Tüm bu bilgiler ışığında Dünya'da da yenilenebilir üretiminin payının arttığını ve $\% 100$ yenilenebilir enerjiye geçişin hızlandığını ve gelişmiş ve gelişmekte olan tüm ülkelerin bu konuda adımlar attığını söylemek mümkündür.

\subsection{Türkiye'de \%100 Yenilenebilir Enerjiye Geçiş}

Tüm dünyada olduğu gibi Türkiye'de de hem enerji talebi hem de enerji üretimi gün geçtikçe artmaktadır. Ancak bu enerji üretiminin ve enerji talebinin artmasına rağmen enerji üretim kaynaklarının temelini oluşturan fosil yakıt kaynaklarının azalması ve fosil yakıt kaynaklarının çevre kirliliği yaratması sebebiyle Dünya $\% 100$ yenilenebilir enerjiye geçişe yönelmektedir. $\mathrm{Bu}$ sebeple alternatif bir enerji kaynağı olan yenilenebilir enerji kaynaklarına ve $\% 100$ yenilenebilir enerjiye geçiş konseptine yönelim ülkemizde de artmıştır. Şekil 4'te Türkiye'de elektrik enerjisi üretiminin kaynak bazında gelişimi incelenmiş ve son 10 yıllık periyot için fosil ve yenilenebilir üretimin payının değişimi verilmiştir. 


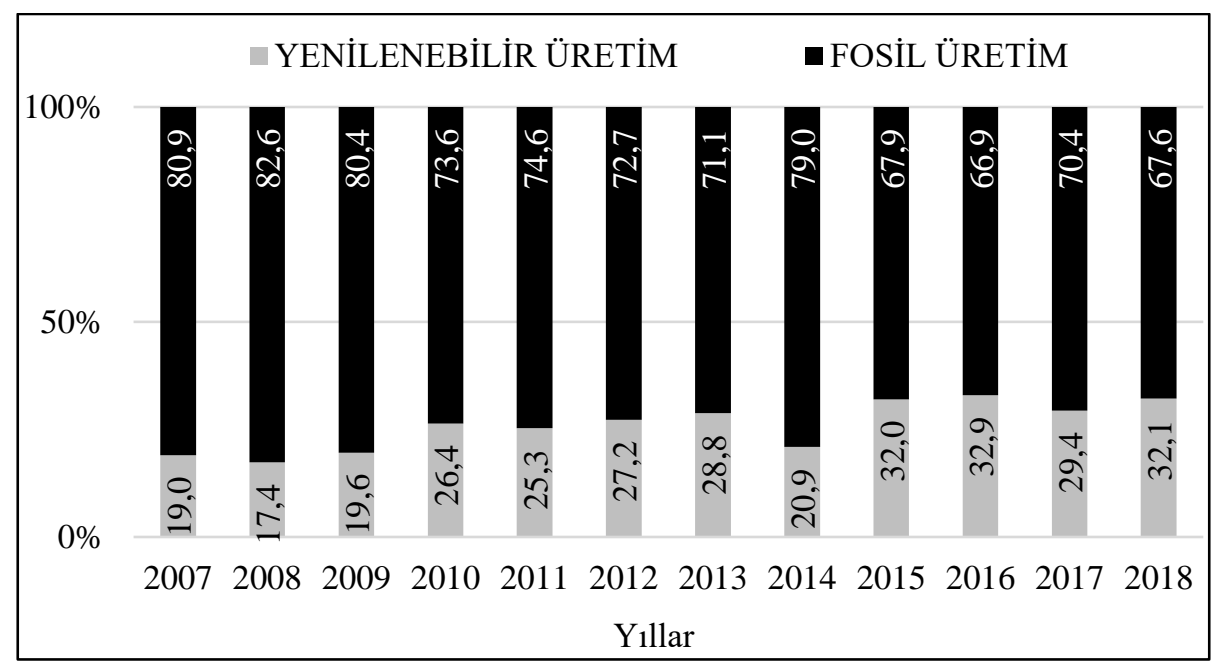

Şekil 4: Türkiye'de Elektrik Enerjisi Üretiminin Kaynak Bazında Gelişimi (TEİAŞ, 2019).

Şekil 4'teki istatiksel verilere göre, 2007 yilından bu yana elektrik enerjisinin kaynak bazında gelişimi farklılık göstermiştir. 2007 yılında Türkiye'de elektrik enerjisi üretiminde fosil üretimin payı \%80 iken bu değer 2018 yılında \%67'lere düşmüş; buna tezat olacak şekilde yenilenebilir üretimin payı 2007 yılından bu yana \%19'lardan \%32'lere yükselmiştir. Bu durumda Türkiye'nin elektrik enerjisi üretiminde $\% 100$ Yenilenebilir Enerjiye Geçiş konsepti için \%12'lik bir artış gösterdiği ve $\% 32$ oranında $\% 100$ yenilenebilir enerjiye geçiş yapabildiği görülmüştür.

2018 yılında elektrik enerjisi üretiminin \%32'i yenilenebilir üretimden $\% 68$ 'sı fosil üretimden ve $\% 0,31$ 'i ise atık 1sıdan sağlanmıştır. 2018 yılı itibariyle $\% 100$ yenilenebilir enerjiye geçişte \%32'lik bir yol kat eden Türkiye'de bu geçişin sağlanmasında hangi yenilenebilir enerji türlerinin katkıda bulunduğu ise Şekil 5 'te verilmiştir.

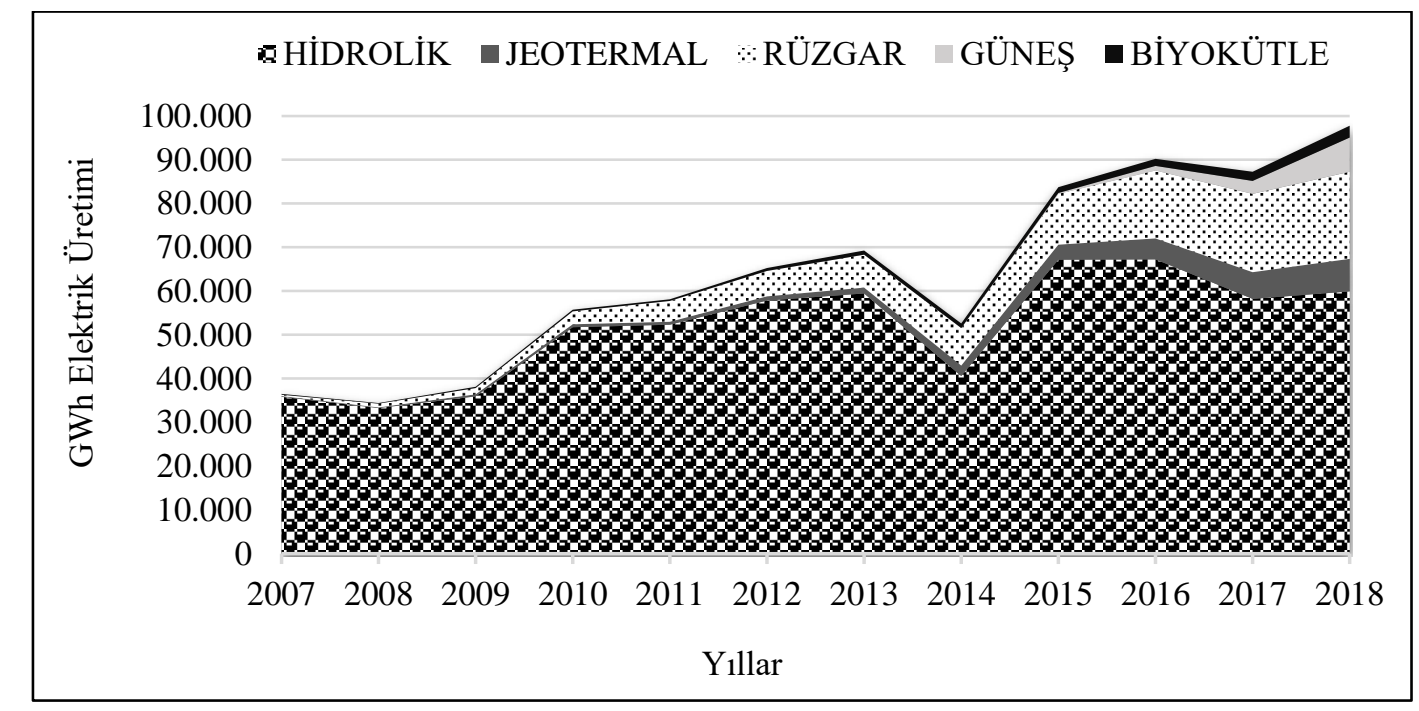

Şekil 5: Türkiye'de Elektrik Enerjisi Üretiminin Yenilenebilir Kaynak Bazında Gelişimi (TEİAŞ,2019).

Şekil 5 incelendiğinde, Türkiye'de elektrik enerjisi üretiminde yenilenebilir kaynak bazında en çok sırasıyla hidrolik enerji, jeotermal enerji, rüzgar enerjisi, güneş enerjisi ve biyokütle enerjisi etkilidir. Her bir yenilenebilir enerji türü 2007 yılından bu yana genel olarak artış göstermiştir. Hidrolik enerji ile 2007 yilında $35.000 \mathrm{GWh}$ elektrik enerjisi üretilirken 2018'de bu rakam 60.000 Gwh'lara ulaşmıştır, jeotermal enerji ile 2007 yilında $156.000 \mathrm{GWh}$ elektrik enerjisi üretilirken 2018'de bu rakam 7400 Gwh'lara ulaşmıştır. Son 11 yıllık periyotta tüm enerji türleri belirgin bir artışla enerji üretimine devam etmiştir. Güneş enerjisi ile elektrik enerjisi üretimi 2014 yılı itibariyle başlamış olup, 2018 yılına gelindiğinde güneş enerjisiyle $7800 \mathrm{Gwh}$ elektrik enerjisi üretilmiştir. Tüm bu enerji türleri arasında 2018 y1lı itibariyle en düşük elektrik enerjisi üretimi payına 2600 Gwh ile biyokütle enerjisi sahiptir. Tüm enerji türlerinin elektrik üretimindeki paylarının 2013-2014 yıllarındaki düşüşünün sebebi ise EPDK tarafından yenilenebilir enerji üretimine getirilen lisanslar ve düzenlemelerdir.

Şekil 6'da ise Türkiye'de elektrik enerjisi üretiminin fosil kaynak bazında gelişimi incelenmiştir. 


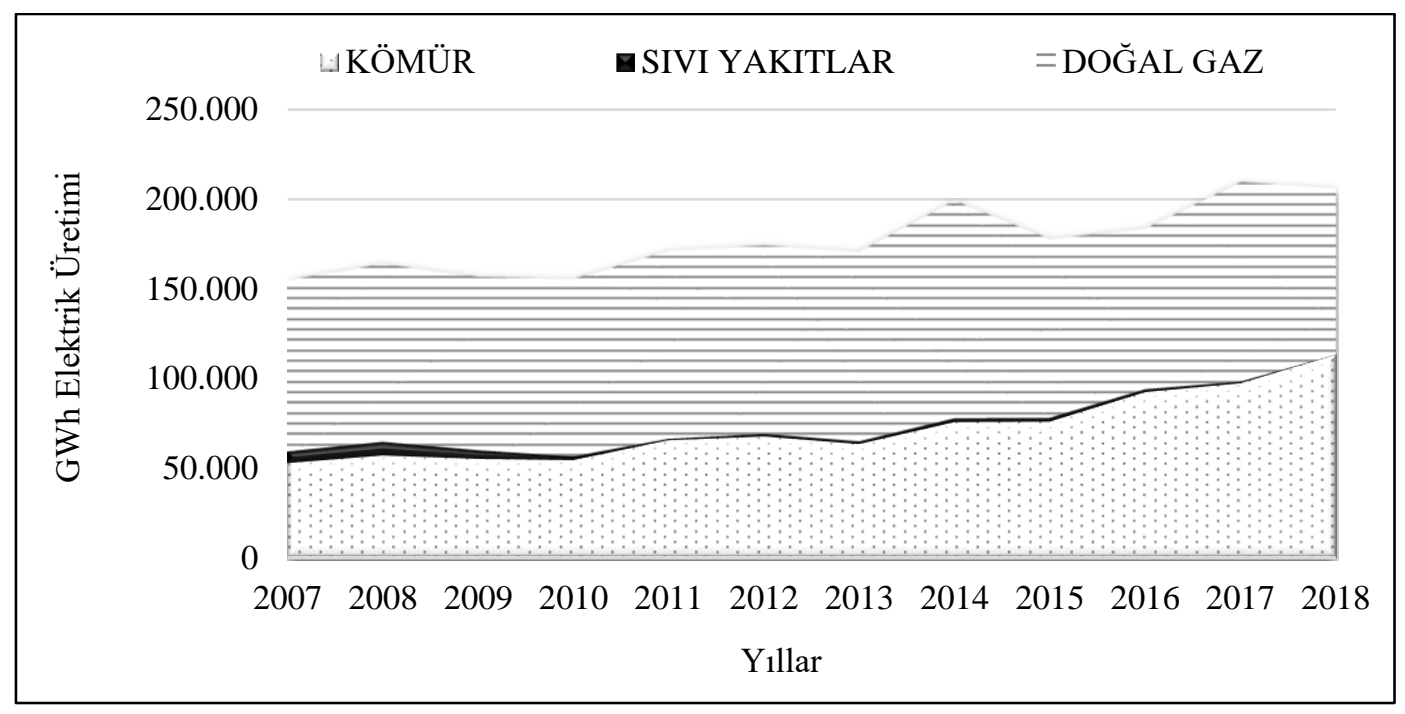

Şekil 6: Türkiye'de Elektrik Enerjisi Üretiminin Fosil Kaynak Bazında Gelişimi (TEİAŞ, 2019).

Türkiye'de elektrik enerjisi üretiminin fosil kaynak bazında gelişimi incelendiğinde ise (Şekil 6) elektrik üretiminde fosil üretimin payının da yüksek olduğu ve Şekil 5'teki yenilenebilir enerji kaynak bazlı elektrik üretimi ile karşılaştırıldığında en yüksek elektrik enerjisi üretiminin hedefin $\% 100$ yenilenebilir enerjiye geçiş olmasına rağmen yenilenebilir olmayan fosil üretimden (kömür ve doğalgaz) sağlandığı görülmüştür. Fosil üretim ile toplam elektrik enerjisi üretimi $206.000 \mathrm{GWh}$ iken; yenilenebilir üretim ile elektrik enerjisi üretimi $97.000 \mathrm{GWh}$ civarındadır. \%100 yenilenebilir enerjiye geçişte yenilenebilir enerji üretim payı artmasına rağmen, fosil üretim payı da artmaktadır bu durumun çözümü için $\% 100$ yenilenebilir enerjiye ve yenilenebilir enerji kullanımına teşvik arttırılmalıdır.

Şekil 7'de Türkiye'nin yenilenebilir kurulu gücünün payı verilmiştir.

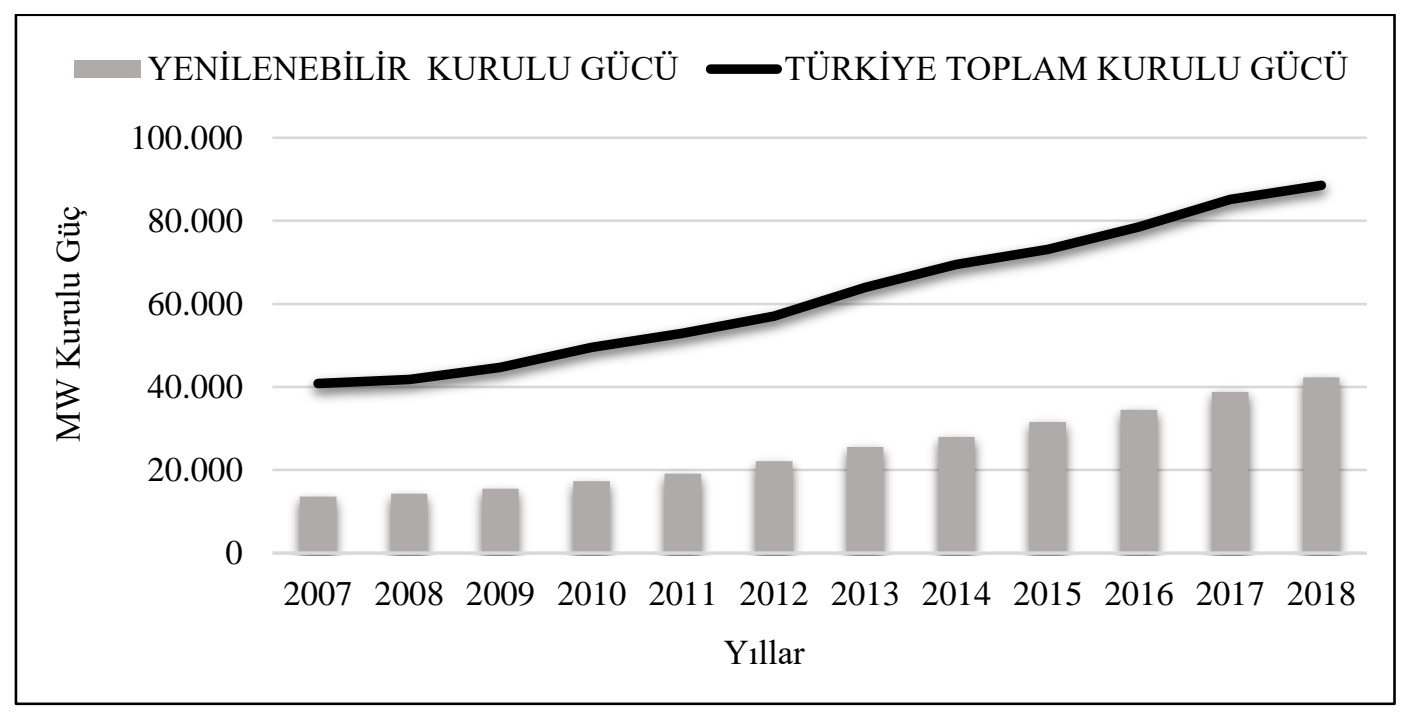

Şekil 7: Türkiye Yenilenebilir Kurulu Gücünün Payı (MW) (TEİAŞ,2019).

Türkiye'de yenilenebilir kurulu gücün payına (MW) bakıldığında (Şekil 7) Türkiye'deki toplam kurulu gücün içerisinde yenilenebilir kurulu gücün payının arttı̆ğ görülmektedir.
Şekil 8'de ise Türkiye'deki toplam elektrik enerji üretiminde yenilebilir enerji üretiminin payı verilmiştir. 


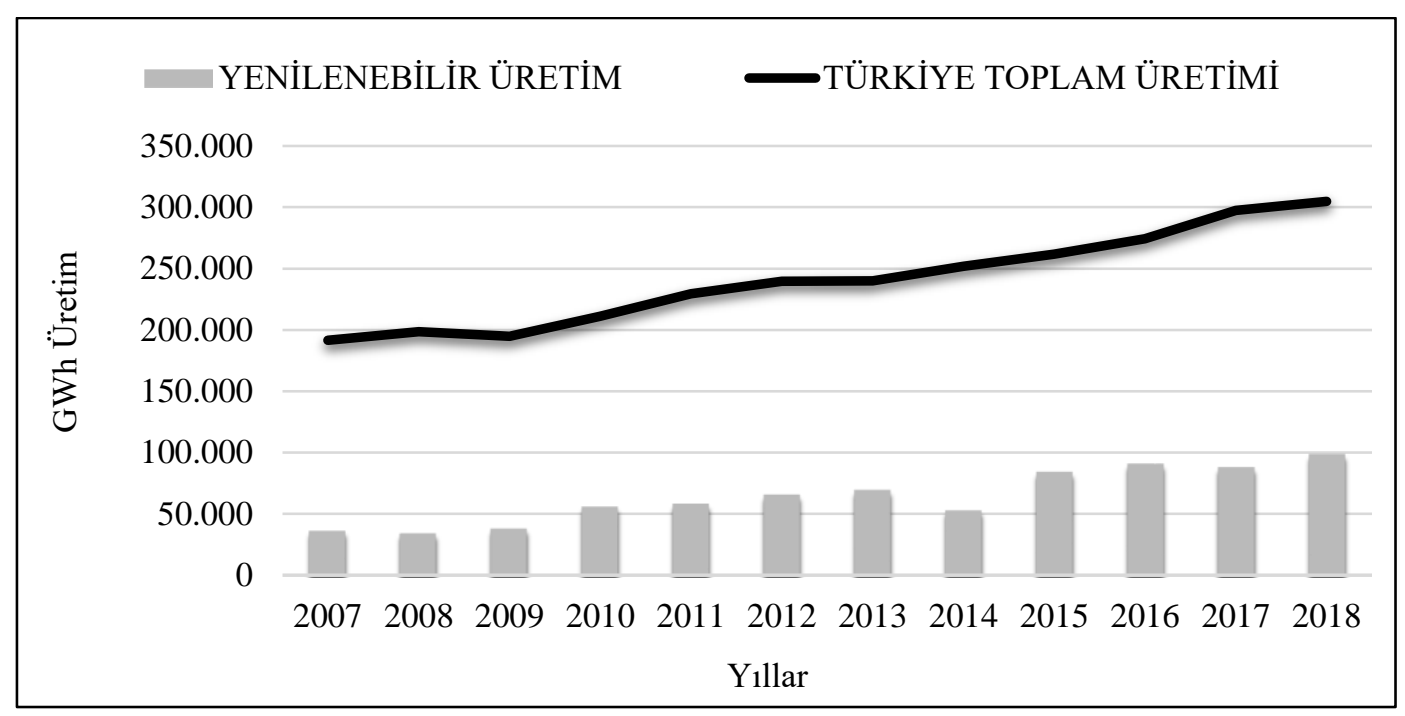

Şekil 8: Türkiye'de Yenilenebilir Elektrik Enerjisi Üretiminin Payl (GWh) (TEİAŞ,2019).

Şekil 8'deki verilere göre, son 11 ylllık periyotta Türkiye'nin toplam elektrik enerjisi üretimindeki yenilenebilir üretim payının arttığı görülmektedir. 2007 de toplam enerji üretiminde yenilenebilir enerjinin üretim pay1 \%19 iken 2018'de bu pay \%32'ye yükselmiştir. Türkiye'nin 2019 yllındaki elektrik enerjisi üretimi Şekil 9'da verilmiştir.

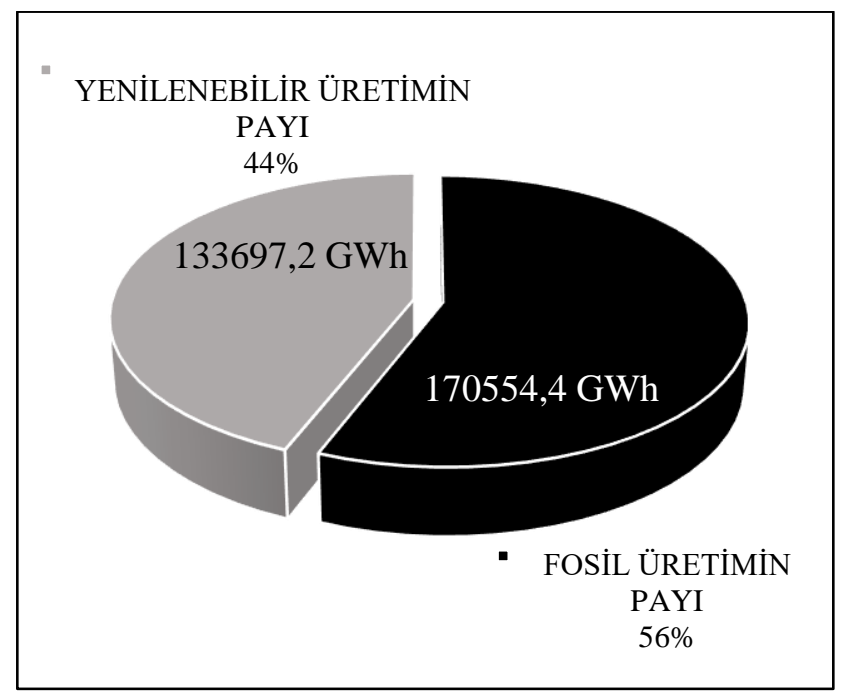

Şekil 9: Türkiye'de 2019 Yll Elektrik Enerjisi Üretimi (TEİAŞ, 2020).

Şekil 9'daki veriler 1şı̆̆ında, 2019 yılında Türkiye'de yenilenebilir enerji kaynaklarından elektrik enerjisi üretiminin 133697,2 GWh ile \%44'lük bir paya sahip olduğu görülmektedir. 2018 yılı ile kıyaslandığında 2019 yılında yenilenebilir elektrik enerjisi üretiminin payı $\% 12$ artmıştır ve Türkiye'de $\% 100$ yenilenebilir enerjiye geçişte son 12 ylllk periyotta en yüksek ilerleme kaydedilmiştir, 2019 yılı \%100 yenilenebilir enerjiye geçişte önemli bir basamak olmuştur.

Türkiye'nin enerji profilinde yenilenebilir enerjinin payının sürekli artıyor oluşu Türkiye'nin \%100 yenilenebilir enerjiye geçişte pozitif yönde ilerlediğini göstermektedir. Ülkemizde değerlendirilmeye açık çok önemli yenilenebilir enerji kaynak potansiyeli bulunmaktadır. Ülkede yaşanan enerji krizlerinin sebebi, enerji planlaması ve yönetiminde uzun yıllardır sürdürülen yanlış politikalardan kaynaklanmaktadır. \%100 yenilenebilir enerjiye geçişte, enerji planlaması ve enerji yönetiminde ülke gerçekleri göz önünde bulundurularak üniversitelerden, meslek odalarından destek alınarak, doğru politikalar oluşturulmalı, yasal düzenlemeler hızlıca yapilmalıdır.

\subsection{Geleceğe Doğru}

Tüm dünyada ve ülkemizde enerji konusu büyük bir problemdir. Enerji problemlerinin çoğu rant sağlama, yatırımların doğru yapılmaması ve riskli projelerden kaynaklanmaktadır. Enerji problemlerinin çözümü için yenilenebilir üretime geçmek, $\% 100$ yenilenebilir enerjiye geçmek en temiz ve doğru çcözüm olacaktır. \%100 yenilenebilir enerjiye geçiş için enerji sektöründeki kar/zarar tartışmalarını bir kenara bırakıp, verimliliği temel alan, bilimsel açıdan uygun, siyasal etkilerden yasalarla korunmuş bir enerji sistemi getirilmelidir.

Ülkemiz elektrik enerjisi üretiminde $\% 75$ oranda dışa bağımlıdır. 5627 sayılı Enerji Verimliliği Kanunu kapsamında uygulanmaya çalışlan yönetmelikler de bu konuda çok önemli bir mesafe alınmasına katkı sağlayamamaktadır. Bu bağımlılık, maalesef siyasi ve ekonomik anlamda da bağımsızlığa engel olmaktadır.

$\% 100$ Yenilenebilir Enerjiye geçişte, hedefi gerçekleștirebilmek için yapılabileceklerden en önemlisi yerel 
yönetimlerin hedefi gerçekleştirmede çabalamasıdır. Yerel yönetim yetkililerinin enerji ile ilgili politikaları oluştururken $\% 100$ yenilenebilir enerjiye geçişi hedeflemesi uygulanabilirliği de olumlu yönde etkileyecektir. Hedefin gerçekleştirilmesi için yapılabilecek genel adımlar ve Türkiye için özel adımlar ise aşağıda maddeler halinde sunulmuştur.

Genel yaklaşımlar;

- $\% 100$ yenilenebilir enerjiye geçişin uygulanabilir ve yararlı olduğunu açıklamak için yetkililerle toplantılar düzenlemek.

- $\% 100$ yenilenebilir enerjiye hızlı bir geçiş için yerel iklim eylem planı geliştirmek.

- Toplumda enerji kontrolü bilincini ve uygulamasını artırarak, enerji tasarrufunu ve erişimini iyileştirmek, temiz enerji üretimini sağlamak, küçük işletme faaliyetlerini desteklemek; yerel yönetim binalarındaki enerji maliyetlerini azaltarak kamu parasından tasarruf etmek, hava ve su kirliliğini azaltmak.

- Ulaşım konusunda toplu taşımayı arttırmak ve yenilenebilir enerjinin ulaşımda kullanılmasını teşvik etmek.

- Yenilenebilir enerjiyi daha sağlıklı, daha erişilebilir ve sürdürülebilir hale getirmek için tüm taşıma sistemlerini elden geçirmek, ulaşım sistemlerindeki fosil yakıt bağımlılığını azaltmak, iklim değişikliği ve hava kirliliği ile mücadele etmek. (Örneğin; toplu ulaşım araçlarında elektrik enerjisine geçmek, şehirdeki fosil yakıtla çalışan arabaları azaltmak ve yasaklamak, elektrikli özel araçlara teşvik vermek.)

- Yerel makamlar, kamu ofisleri dahil olmak üzere mümkün olan her yerde yenilenebilir enerji kaynaklarının kullanımına geçmek ve binaları enerji bakımından verimli hale getirmek.

- $\% 100$ yenilenebilir enerjiye geçiş yapmış ülke, şehir, kurum ve kuruluşlarla birlikte çalışarak onların tecrübelerinden yararlanarak ortak fikir paylaşımı irtibata geçmek ve izledikleri yolu incelemek.

- İklim değişikliğinden en çok etkilenen, hava, toprak, su kirliliği gibi fosil yakıtların doğrudan etkilerini yaşayan toplulukların yeni bir enerji sistemine geçerken lider olmasi.

- Tüm tıbbi otoritelerin fosil yakıtların özellikle hava kirliliği yoluyla halk sağlığına verdiği zararı kabul etmesi sebebiyle, öncelikle tıbbi derneklerin, hastanelerin ve sağlık merkezlerinin, \%100 yenilenebilir enerjiye hızlıca geçişini sağlamak.

- Genişleyen yenilenebilir enerji sektöründe işçilerin yeniden eğitilmesini ve istihdamın yenilenmesini sağlamak.

- $\mathrm{Bu}$ konu hakkında çalışmalar yapan sendikalar ve gençlik örgütlerinin, fosil yakıt sektöründe çalışan işçiler de dâhil olmak üzere herkes için yenilenebilir enerjiye geçişte istihdam verilmesini sağlaması (URL2).

Türkiye için öncelikli yaklaşımlar;
- Jeotermal enerji bakımından dünya ülkeleri arasında zengin konumda olan ve aktif bir tektonik kuşak üzerinde yer alan Türkiye'de, jeotermal enerji potansiyeli oluşturan alanların \%78'i Batı Anadolu'da, \%9'u İç Anadolu'da, \%7'si Marmara Bölgesi'nde, \%5'i Doğu Anadolu'da ve \%1'i diğer bölgelerde yer almaktadır.

- 2008 yılında, Jeotermal Kaynaklar ve Doğal Mineralli Sular Kanunu'nun yürürlüğe girmesi ve özel sektörün de jeotermal arama, geliştirme ve yatırım çalışmaları ile birlikte ülkemizin toplam jeotermal is1 kapasitesi (görünür 1sı miktarı) 35.500 MW'a ulaşmıştır (URL5).

- Jeotermal enerji kaynaklarının arama ve ortaya çıkarılması çalışmalarına hı vermek, mevcut kaynakların geliştirilmesini sağlamak ve jeotermal enerji aramaları için sağlanan ödenekleri artırmak.

Türkiye'de yenilenebilir enerji ile elektrik üretiminde en çok kullanılan iki yenilenebilir enerji türü rüzgar ve güneş enerjisidir. 2018 y1lında güneş enerjisi ile elektrik enerjisi üretimi 7800 Gwh olmuştur (TEİAŞ, 2019). Yine elektrik üretiminde rüzgar enerjisinin payı da ülkemiz için önemlidir. Bu sebeple hem rüzgar hem de güneş enerjisi ile elektrik üretimi payının artması için her iki enerji türünün de kaynaklarının artırılması, bu konu ile ilgili yatırımlara önem verilmesi gerekmektedir.

\section{Sonuç ve Değerlendirme}

Dünya iklim değişikliklerinin etkileri nedeniyle bir dönüm noktasındadır. Artan nüfus, enerji talebi ve enerji kullanımıyla birlikte enerji konusu problem haline gelmiştir. Fosil üretimin yarattığı çevre kirliliği ve olumsuzlukların aksine yenilenebilir üretimin avantajları dünyanın \%100 yenilenebilir enerjiye geçişini zorunlu kılmaktadır. Güneş, rüzgar, hidro elektrik de dahil olmak üzere yenilenebilir enerji kaynakları daha az karbon ve daha çok sürdürülebilir bir enerji sistemine geçişin merkezindedir. Güneş, bir yılda tüm dünyanın kullanabileceğinden çok daha fazla enerji sağlayabilen yenilenebilir enerji kaynaklarından sadece birisidir, bunun yanısıra yenilenebilir enerji kaynaklarına ne kadar yatırım yapılırsa, elektrik üretiminin de o kadar ucuz olacağı apaçık bir gerçektir. \%100 yenilenebilir enerji ile çalışan bir dünyaya ulaşmak için hem yerel hem de küresel anlamda kat edilmesi gereken çok yol vardır.

Hem Dünya'da hem de ülkemizde \%100 yenilenebilir enerjiye geçişte önemli bir yol kat edilmiştir. 2007 yılından bu yana Türkiye'de elektrik enerjisi üretiminde fosil üretimin payı $\% 80$ 'den \%67'ye düşmüş; yenilenebilir üretimin payı da \%19'lardan \%32'lere yükselmiştir. Türkiye'nin elektrik enerjisi üretiminde $\% 100$ Yenilenebilir Enerjiye Geçiş konsepti için $\% 12$ 'lik bir artış gösterdiği ve $\% 32$ oranında $\% 100$ yenilenebilir enerjiye geçiş yapabildiği görülmüştür. Ancak bu payın arttırılması mümkündür çünkü Türkiye'de yenilenebilir enerji kaynaklarının potansiyeli çok yüksektir. Bu potansiyele bağlı olarak ülkemizin enerji talebinin yenilenebilir üretimle karşılanması da mümkündür. Dünya'ya bakıldığında ise 2018 yılı Uluslararası Enerji Ajansı verilerine göre yenilenebilir enerji kaynaklı küresel elektrik üretimi payı \%26 olarak hesaplanmıştır. $\mathrm{Bu}$ durum küresel çapta $\% 100$ yenilenebilir enerjiye geçişe $\% 26$ oranında geçiş yapıldığı göstermektedir. İskoçya, 2020 yılına kadar tüm elektrik enerjisini yenilenebilir enerji kaynaklarından üretmeyi hedeflemektedir. Arnavutluk, 
Norveç ve Kosta Rika \%100 yenilenebilir enerjiye geçiş sağlamış ülkelerdendir. Tüm bu bilgiler ışığında Dünya'da da yenilenebilir üretiminin payının arttığını ve \%100 yenilenebilir enerjiye geçişin hızlandığını söylemek mümkündür.

Bu geçişi daha da hızlandırmak ve daha temiz bir dünyada yaşayabilmek için küresel/yerel düzeyde birçok adım atmak gereklidir. Öncelikle tabandan ulusal/küresel seviyeye doğru bir geçiş yapılmalıdır. Önce mahalle ve şehirde sonra ülkede ve son olarak dünyada \%100 yenilenebilir enerjiye geçiş adım adım sağlanmalıdır. Bunun için yerel yönetimlere büyük görev düşmektedir. Fosil yakıt projelerinin ve fosil yakıt bütçesinin azaltılması, öncelikle yerel yönetim kurumları başta olmak üzere tüm devlet kurumlarının \%100 yenilenebilir enerjiye geçmesi, $\% 100$ yenilenebilir enerji ekonomisine geçişin desteklenmesi bu konuda atılabilecek önemli adımlardır. Yerel yönetim yetkililerinin enerji ile ilgili politikaları oluştururken \%100 yenilenebilir enerjiye geçişi hedeflemesi uygulanabilirliği de olumlu yönde etkileyecektir. Toplumda enerji kontrolü bilincini ve uygulamasını artırmak, ulaşımda, ısıtma ve elektrik üretiminde yenilenebilir enerjiyi desteklemek de bu konuda önemli adımlar olacaktır.

$\% 100$ yenilenebilir enerjiye geçiş hem enerji tasarrufu sağlayacak hem temiz enerji üretimi olanağı yaratacak hem de daha sağlıklı, daha erişilebilir ve sürdürülebilir bir enerji sistemi oluşturacaktır.

\section{Kaynakça}

Avcıoğlu, A. O., Dayığlu, M. A., Türker, U. (2019) Assessment of the energy potential of agricultural biomass residues in Turkey, Renewable Energy, 138, 610-619.

Child, M., Kemfert, C., Bogdanov, D., Breyer, C. (2019) Flexible electricity generation, grid exchange and storage for the transition to a $100 \%$ renewable energy system in Europe. Renewable Energy, 139, 80-101.

Hansen, K., Mathiesen, B. V., Skov, I. R. (2019) Full energy system transition towards $100 \%$ renewable energy in Germany in 2050. Renewable and Sustainable Energy Reviews, 102, 1-13.

Hosseini, S. E., Wahid, M. A. (2016) Hydrogen production from renewable and sustainable energy resources: promising green energy carrier for clean development. Renewable and Sustainable Energy Reviews, 57, 850-866.

Kanat, G. \& Ergüven, G. Ö. (2020) Importance of solid waste management on composting, problems and proposed solutions: The case of Turkey. Avrupa Bilim ve Teknoloji Dergisi, (19), 66-71.

Karabağ, N. (2018) Atık gazlaştırma prosesi ile hidrojen gazı üretiminin bilgisayar destekli modellemesi ve simülasyonu. Yüksek Lisans Tezi, İstanbul Üniversitesi Fen Bilimleri Ensititüsü.

Kilıçkaplan, A., Bogdanov, D., Peker, O., Caldera, U., Aghahosseini, A., Breyer, C. (2017) An energy transition pathway for Turkey to achieve $100 \%$ renewable energy powered electricity, desalination and non-energetic industrial gas demand sectors by 2050. Solar Energy, 158, 218-235.

Murdock, H. E., Gibb, D., André, T., Appavou, F., Brown, A., Epp, B., ..., Sawin, J. L. (2019) Renewables 2019 Global Status Report., International Energy Agency, Renewables.

Mutlubaş, H., Özdemir, Z. Ö. (2019) Hydrogen as an energy carrier and hydrogen production methods. Bartın Üniversitesi Uluslararasi Fen Bilimleri Dergisi, 2(1), 16-34.

Pandey, B., Karki, A. (2016) Hydroelectric energy: renewable energy and the environment. CRC Press.

Ploetz, R., Rusdianasari, R., Eviliana, E. (2016). Renewable energy: Advantages and disadvantages. In proceeding forum in research, science, and technology (FIRST) 2016. Politeknik Negeri Sriwijaya.

Renewables 2019, Global Status Report, REN21, https://www.ren21.net/, Erişim Tarihi: 23.01.2020

Sadiqa, A., Gulagi, A., Breyer, C. (2018) Energy transition roadmap towards $100 \%$ renewable energy and role of storage technologies for Pakistan by 2050. Energy, 147, 518-533.

Shamshirband, S., Rabczuk, T., Chau, K. W. (2019) A survey of deep learning techniques: Application in wind and solar energy resources. IEEE Access, 7, 164650-164666.

TEİAŞ, 2019, Türkiye Elektrik İletim A.Ş., https://www.teias.gov.tr/ , Erişim Tarihi: 23.01.2020.

TEİAS, 2020, Türkiye Elektrik İletim A.Ş., https://www.teias.gov.tr/ , Erişim Tarihi: 04.06.2020.

Uluslararası Enerji Ajans1, 2019, https://www.iea.org/, Erişim Tarihi: 23.01.2020.

URL1: http://www.yegm.gov.tr/, Erişim Tarihi: 25.12.2019, Konu: Jeotermal Enerji.

URL2: $\quad$ https://gofossilfree.org/get-organising-100-re/. 23.01.2020, 11.50, Konu: Get organising: A Fast \& Just Transition to $100 \%$ Renewable Energy.

URL3: https://www.iea.org/topics/renewables/, Erişim Tarihi: 25.12.2019, Konu: Renewables.

URL4: https://www.teias.gov.tr/, Erişim Tarihi: 25.12.2019, Konu: Türkiye Elektrik Enerjisi.

URL5: http://www.mta.gov.tr/v3.0/hizmetler/jeotermal-harita, Erişim Tarihi: 29.01.2020, Konu: Jeotermal Enerji.

URL6: https://www.statista.com/statistics/302274/china-powergeneration/, Erişim Tarihi: 23.01.2020, Konu: Çin Yenilenebilir Elektrik Enerji Üretimi.

URL7: https://www.statista.com/statistics/302203/chinaelectricity-consumption/, Erişim Tarihi:23.01.2020, Konu: Çin Elektrik Enerjisi Tüketimi.

Uyar, T. S., Beşikci, D. (2017) Integration of hydrogen energy systems into renewable energy systems for better design of $100 \%$ renewable energy communities. International Journal of Hydrogen Energy, 42(4), 2453-2456.

Veziroglu, T. N., Sahin, S. (2019) 21st Century's energy: Hydrogen energy system. Международньй научный журнал Альтернативная энергетика и экология, (4-6), 14-27.

Wilberforce, T., El Hassan, Z., Durrant, A., Thompson, J., Soudan, B., Olabi, A. G. (2019) Overview of ocean power technology, Energy, 175, 165-181. 